\title{
PENGARUH PELATIHAN MOTIVASI KEYAKINAN DIRI \\ TERHADAP SELF EFFICACY PEGAWAI \\ UNIVERSITAS X DI KOTA PALANGKARAYA
}

\author{
Oleh \\ Dina Fariza Tryani Syarif \\ Program Studi Bimbingan Konseling FKIP Universitas Muhammadiyah Palangkaraya
}

\begin{abstract}
ABSTRAK
Penelitian ini bertujuan untuk meningkatkan self efficacy pegawai Universitas $X$ melalui pelatihan motivasi keyakinan diri. Alat pengumpulan data yang digunakan dalam penelitian ini adalah skala self efficacy dan intervensi yang digunakan ialah pelatihan motivasi keyakinan diri.

Data yang diperoleh dalam penelitian ini dianalisis menggunakan Independent Sample t-test dengan program sistem komputasi Statistical Package for Social Science (SPSS 16.0 for Windows).

Hasil analisis menggunakan Independent Sample $t$-test menunjukkan bahwa nilai $t=-2,515$ dengan $p=0,015(p<0,05)$. Kesimpulan penelitian ini adalah ada pengaruh pelatihan motivasi keyakinan diri terhadap efikasi diri pegawai.
\end{abstract}

\section{Kata kunci: self efficacy dan pelatihan motivasi keyakinan diri}

\section{PENDAHULUAN}

Institusi pendidikan berbagai jenjang dapat ditemukan di Kota Palangkaraya. Universitas $\mathrm{X}$ merupakan salah satu insititusi penyelenggara pendidikan di Kota Palangkaraya yang terus berupaya menghasilkan akademisi dengan mutu yang baik, dengan memperbaiki kualitas layanan sehingga mampu menghasilkan out put (dalam hal ini adalah lulusan) yang up to date dan mampu bersaing dalam era persaingan yang demikian ketat saat ini.

Salah satu upaya yang dilakukan oleh Universitas $X$ untuk meningkatkan kualitas dan mengikuti perkembangan zaman adalah dengan melakukan peningkatkan kualitas kinerja pegawai. Hasil wawancara yang dilakukan peneliti kepada Wakil Rektor II Universits $X$ perlu adanya peningkatan terutama mengenai motivasi pegawai yang cenderung rendah, hal ini terlihat dari lambannya pegawai dalam menylesaikan pekerjaan yang telah di disposisi kepada pegawai yang bersangkutan.

Teori Bandura (1997) mengemukakan bahwa tinggi rendahnya efikasi atau keyakinan karyawan dapat dilihat dari empat aspek yaitu kesadaran akan potensi diri, pesepsi positif, personal goal dan daya juang. Kesadaran akan potensi diri merupakan pemahaman untuk mengenali kelebihan dan kekurangan diri sendiri. Kemampuan membentuk persepsi positif merujuk pada kemampuan membangun pemikiran positif dengan memanfaatkan kesempatan sehingga individu mampu bertindak secara objektif. Personal goal merupakan proses penetapan sasaran atau tujuan dalam bidang pekerjaan untuk mencapai keberhasilan kinerja. Daya juang merupakan usaha yang perlu diupayakan dan ketahanan dalam menghadapi kesulitan.

Rendahnya efikasi diri pegawai ditinjaui dari kesadaran karyawan akan potensi diri ditunjukkan kurangnya keyakinan untuk mengeksekusi tindakantindakan yang diperlukan dalam pekerjaannya, selalu membutuhkan arahan dan bimbingan dari atasan, selalu meminta koreksi dari atasan terhadap hasil kerjanya sebelum diserahkan kepada atasan universitas, membutuhkan referensi bahan untuk menyelesaikan pekerjaannya, tidak yakin terhadap kemampuannya dalam menyelesaikan tugas meskipun subjek telah memiliki pengetahuan dan pengalaman untuk menyelesaikan tugas pekerjaannya, tidak percaya diri terhadap hasil kerja, merasa canggung dalam bertugas, melimpahkan tugas kepada orang lain karena 
menilai dirinya tidak mampu, tidak yakin menyelesaikan tugas yang dinilai berat.

Kurang adanya personal goal secara umum ditunjukkan dengan tidak adanya pengaturan sumber daya yang baik dalam menyelesaikan tugas, rendahnya motivasi untuk mencapai tujuan, adanya prokastinasi dalam menyelesaikan tugas, tidak ada manajemen atau pengaturan waktu yang baik dalam menyelesaikan tugas, tidak memiliki skala prioritas dalam menyelesaikan tugas. Keyakinan diri dalam penyelesaian tugas pekerjaan yang dimanifestasikan dalam bentuk personal goal sangat dibutuhkan untuk pencapai kinerja yang optimal. Mousolides \& Philippou (2005) mengemukakan bahwa keyakinan diri yang tinggi ditandai dengan kemampuan penguasaan terhadap orientasi tujuan eksternal seperti batas pengerjaan tugas, waktu penyusunan tugas. Sejalan dengan hal itu Pintrich (2000) menyatakan bahwa kemampuan seseorang dalam penguasaan kemampuan penetapan tujuan secara individu (personal goal) dapat mengembangkan kompetensi diri sehingga mampu meyelesaikan persoalan yang di anggap sulit.

Daya juang yang rendah dalam mengatasi hambatan dalam menyelesaikan pekerjaan ditujukkan dengan perilaku menunda atau bahkan tidak menyelesaikan masalah yang ditemui saat bekerja sehingga masalah yang awalnya merupakan masalah yang sepele berkembang menjadi masalah yang lebih besar. Selain itu cenderung melimpahkan kepada orang lain dalam menghadapi atau menyelesaikan masalah tersebut.

Berdasarkan uraian di atas maka dapat terungkap bahwa rendahnya tingkat efikasi diri pegawai Universitas $X$ disebabkan karena karyawan tidak yakin kepada kemampuan, keahlian maupun pengalaman yang telah dimilikinya dalam menangani berbagai tugas dalam pekerjaannya. Oleh sebab itu diperlukan usaha peningkatan efikasi diri pada pegawai Universitas X. Peningkatan efikasi tersebut sebagai bentuk pemanfaatan sumber daya organisasi yang efektif. Selain itu dengan adanya peningkatan efikasi diri akan memberikan determinasi pada inisiatif perilaku meliputi seberapa besar usaha yang dilakukan, berapa lama ketahanan dalam menghadapi kesulitan dan kenyataan yang terjadi (Bandura, 1977). Peningkatan efikasi diri diharapkan akan berdampak pada munculnya inisiatif pegawai untuk melakukan tindakan yang diperlukan dalam pekerjaannya, mempunyai keyakinan dan kemantapan bertindak dalam menyelesaikan tugas-tugas pekerjaannya.

Pelatihan motivasi keyakinan diri pada pegawai Universitas $X$ dimaksudkan untuk meningkatkan efikasi diri pegawai sehingga pegawai memiliki keyakinan untuk melakukan tindakan yang diperlukan dalam pekerjaannya. Keyakinan tersebut sangat penting sesuai dengan pendapat Bandura (1977) yang menyatakan bahwa konsep manusia sebagai agency dan beliefs of personal efficacy berperan penting. Semakin rendah tingkat keyakinan terhadap dampak yang dihasilkan dari tindakan yang dilakukan makin rendah pula dorongan individu untuk melakukan tindakan tersebut. Tierney \& Farmer (2002) menyatakan dengan meningkatkan motivasi keyakinan diri karyawan dapat mengurangi perasaan takut, cemas dan ragu-ragu yang mungkin timbul ketika karyawan menghadapi pekerjaan, baik pekerjaan yang sudah biasa dilakukan maupun tugas pekerjaan baru.

Berdasarkan urain di atas maka dapat disimpulkan bahwa perlu diteliti dalam usaha mempengaruhi efikasi diri dalam penelitian ini dengan memberikan intervensi berupa pelatihan motivasi keyakinan diri kepada pegawai Universitas X Palangkaraya..

\section{LANDASAN TEORI}

\section{Efikasi Diri}

Pengertian Efficccy (Efikasi)

Efikasi didefinisikan oleh Bandura

(1997) sebagai kemampuan generatif dari ketrampilan kognitif, sosial, emosional dan keperilakuan yang diorganisasikan dan 
disusun secara efektif untuk mencapai tujuan. Berdasarkan pendapat tersebut, maka dalam efikasi terdapat tiga pokok pikiran yaitu : a) Efikasi merupakan kemampuan yang dibentuk oleh aspek kognitif, sosial, emosional, dan keperilakuan, b) Efikasi berhubungan dengan ketrampilan (sub skill) untuk mengorganisasi dan mengatur secara efektif, dan c) Efikasi mempunyai titik akhir berupa tujuan yang ingin dicapai.

Dari ketiga pokok pikiran yang diuraikan di atas maka dapat disimpulkan bahwa efikasi adalah ketrampilan untuk mengatur dan mengorganisasikan secara efektif kemampuan kognitif, sosial, emosional, dan perilaku yang berhubungan dengan usaha individu untuk mencapai suatu tujuan. Artinya, efikasi menentukan perilaku yang dilakukan oleh individu dalam usahanya untuk mencapai tujuan tertentu.

Pengertian Self Efficacy (Efikasi Diri)

Menurut Bandura (1997) penilaian efikasi diri (perceived self efficacy) mengacu pada keyakinan seseorang terhadap kemampuannya untuk mengorganisir dan melaksanakan berbagai tindakan yang diperlukan guna memperoleh pencapaian yang tertentu. Berdasarkan pendapat tersebut, untuk menilai efikasi seorang individu ditentukan pada keyakinannya terhadap kemampuan yang dimiliki untuk mengorganisir dan mengeksekusinya menjadi tindakan yang diperlukan guna mencapai hasil tertentu.

Pusat efikasi diri adalah keyakinan yang ada pada diri individu. Pentingnya keyakinan diri dipertegas dengan pendapat Bandura (1997) yang menyatakan bahwa keyakinan terhadap kemampuan diri sendiri sebagai faktor kunci manusia sebagai agen. Jika seseorang percaya mereka tidak memiliki kemampuan untuk menghasilkan manfaat maka, individu tersebut tidak akan mencoba untuk membuat berbagai hal terjadi. Seperti dicontohkan bahwa orang yang berbeda namun memiliki ketrampilan yang sama ataupun orang yang sama tetapi dalam situasi yang berbeda dapat menunjukkan perilaku yang kurang baik, cukup baik, atau bahkan luar biasa bergantung pada fluktuasi keyakinan dirinya.

Bandura (1997) menyatakan bahwa yang patut menjadi perhatian dalam konsep ini adalah adanya perbedaan antara mempengaruhi ketrampilan dan mengintegrasikan ketrampilan tersebut dalam tugas kemudian mengeksekusi dengan baik tindakan tersebut dalam situasi yang sulit. Bahkan kadang-kadang seorang individu mengalami kegagalan dalam menunjukkan kinerja yang optimal meskipun individu tersebut telah mengetahui dengan jelas apa yang harus dikerjakan dan dibekali ketrampilan yang dibutuhkan dalam pekerjaannya. Gagasan atas referensi diri akan mengaktifkan proses kognitif, motivasional dan afektif, yang akan mengarahkan penegtahuan dan kemampuan menjadi tindakan yang akan dilakukan.

Berdasarkan pada pendapat di atas maka dapat disimpulkan bahwa efikasi diri adalah keyakinan inividu pada kemampuannya untuk mengatur dan mengeksekusi segala bentuk tindakan yang diperlukan dalam usahanya untuk mendapatkan hasil seperti yang diinginkan, dimana kemampuan tersebut diperoleh dari ketrampilan kognitif, sosial, emosional dan keperilakuan.

\section{Dimensi Efikasi Diri}

Menurut Bandura (1977) ekspektasi efikasi dibedakan menjadi tiga dimensi, yaitu

a) Tingkat tugas yaitu dimensi mengenai tingkatan tugas yang harus diselesaikan individu dari tuntutan yang sederhana, moderat sampai yang membutuhkan performansi maksimal (sulit).

b) Luas bidang tugas yaitu dimensi yang berhubungan dengan luas bidang tugas yang dihadapi individu. Efikasi individu mungkin hanya terbatas pada bidang tertentu sementara individu yang lain bisa meliputi beberapa bidang sekaligus. 
c) Tingkat kekuatan yakni dimensi yang terkait dengan kekuatan atau kemantapan individu terhadap keyakinannya. Individu dengan efikasi diri tinggi cenderung pantang menyerah, ulet dalam usaha walaupun menghadapi rintangan dibandingkan individu dengan efikasi diri rendah.

Berdasarkan penjelasan di atas maka dapat disimpulkan bahwa dimensi efikasi diri ditentukan oleh tingkat tugas (dari mudah hingga sulit), luas bidang tugas (dari sederhana hingga kompleks) dan tingkat kekuatan (dari lemah hingga kuat). Artinya, sejauhmana efikasi diri individu dapat diukur dari tingkatannya, luasnya dan kekuatannya.

Sumber-sumber Informasi yang

Mempengaruhi Efikasi Diri

Ekspektasi efikasi diri berdampak pada perilaku individu yang didasari pada kepercayaannya terhadap kemampuan untuk menghadapi situasi akan mengakibatkan perilaku yang ketekunan dan dapat pula mengakibatkan perilaku untuk menghindari situasi yang tidak mampu untuk dihadapi. Menurut Bandura (1977) terdapat empat sumber informasi ekspektasi efikasi diri, yaitu :

a). Pencapaian yang sukses

Individu yang sebelumnya pernah mencapai pengalaman sukses dalam tugas akan memiliki keyakinan yang tinggi terhadap kemampuannya, sehingga meningkatkan keyakinannya saat menghadapi tugas berikutnya sebaliknya individu yang sebelumnya gagal akan merasa tidak mampu sehingga menurunkan keyakinannya saat menghadapi tugas berikutnya.

b). Pengalaman orang lain

Efikasi diri individu dapat dipengaruhi oleh pengalaman orang lain melalui model pendekatan sosial yaitu apabila individu yang dianggap memiliki kemampuan sama dan memperoleh keberhasilan maka akan meningkatkan efikasi diri sebaliknya jika inidivu lain tersebut gagal maka dapat menurunkan efikasi diri. Faktor ini sangat tergantung pada karakteristik, tingkat kesulitan tugas, keadaan situasional dan keanekaragaman hasil yang dicapai oleh model. Bila model yang diamati tidak memiliki tingkat kesamaan dengan karakteristik individu maka pengaruh efikasi juga makin kecil.

c). Persuasi sosial

Saran, nasihat dan bimbingan yang positif dari orang lain dapat meningkatkan keyakinan tentang ketrampilan dan kemampuan individu. Pada sumber informasi ini termasuk didalamnya bujukan secara lisan. Ada dua kondisi yang mempengaruhi persuasi secara verbal yakni: (a) ada kepercayaan terhadap orang yang memberi saran; dan (b) tindakan yang disarankan untuk dicoba harus realistis bagi yang diberi saran.

d). Kondisi psikologis dan emosional

Individu yang memiliki rasa takut, kecemasan dan stres akan gagal menyelesaikan tugas. Kondisi tersebut akan membuat individu merasa tidak mampu dan tidak yakin untuk menghadapi tugas selanjutnya. Individu akan lebih berhasil apabila tidak mengalami pengalaman yang menekan yang dapat menurunkan keyakinannya. Tinggi rendahnya efikasi diri bila dikaitkan dengan lingkungan yang responsif dan tidak responsif akan menghasilkan empat bentuk hubungan yaitu: (1) Jika efikasi diri tinggi dan lingkungan responsif maka individu akan sukses, (2) Jika efikasi diri rendah dan lingkungan responsif maka individu akan mengalami depresi ketika melihat individu lain sukses pada tugas yang dianggap sulit, (3) Jika efikasi diri tinggi dan lingkungan kurang responsif maka individu akan protes melalui gerakan sosial atau kekuatan untuk memaksakan perubahan namun jika usahanya gagal maka mereka akan menyerah dan mencari cara lain atau mencari lingkungan baru yang lebih responsif dan (4) Jika efikasi diri rendah dan 
lingkungan kurang responsif maka individu akan apatis, menyerah dan tidak berdaya.

Berdasarkan penjelasan di atas maka dapat disimpulkan bahwa sumber informasi yang mempengaruhi efikasi diri adalah pencapaian yang sukses, pengalaman orang lain, persuasi sosial, dan kondisi psikologis dan emosional. Keempat sumber informasi tersebut dapat mempengaruhi efikasi individu dengan cara yang berbeda-beda dan tingkat efikasi yang berbeda-beda pula.

\section{Pelatihan Motivasi Keyakinan Diri}

Definisi Pelatihan Motivasi Keyakinan Diri

Menurut Cummings \& Worley (2005) pelatihan adalah proses pendidikan dalam jangka waktu yang relatif pendek dengan menggunakan prosedur yang telah sistematis dan terorganisir sehingga tenaga kerja non manajerial dapat mempelajari pengetahuan dan keterampilan teknis untuk tujuan tertentu. Sesuai definisi pelatihan di atas maka pelatihan tidak dapat dipisahkan dengan proses belajar yang terjadi pada subjek. Oleh sebab itu pelatihan juga merupakan metode intervensi yang dilakukan pada subjek dengan memberikan berbagai informasi sebagai sumber pengetahuan yang kemudian akan diproses oleh peserta pelatihan (subjek).

Locke (2003) mengemukakan bahwa unsur-unsur dalam pengetahuan adalah kemampuan memahami yang merupakan basis dari semua pengetahuan, indentifikasi yang merupakan integrasi pada persepsi terhadap materi, persepsi positif dan konsep pengetahuan atau memori dan kemampuan yang merupakan kemampuan untuk melakukan sesuatu. Berbagai tingkatan pengetahuan bergantung pada berbagai proses aktif terhadap informasi (berfikir) dan feedback pada tindakan. Semuanya akan mengarahkan pada realisasi kognitif psikologis termasuk belajar, memori, pemecahan masalah dan pengambilan keputusan.

Efikasi diri individu merupakan keyakinan individu pada kemampuan yang dimiliki untuk mengatur dan mengeksekusi tindakan yang diperlukan dalam melakukan tugas dalam pekerjaannya. Oleh sebab itu, pelatihan motivasi keyakinan diri dalam penelitian ini adalah proses pendidikan dalam jangka pendek dan dilakukan dengan memberikan pengetahuan yang memuat unsur kemampuan dalam memahami, mengidentifikasi, persepsi dan konsep pengetahuan serta kemampuan mengenai efikasi diri. Lebih jelas mengenai materi pengetahuan yang diberikan pada peserta pelatihan akan dijelaskan pada uraian selanjutnya.

Aspek-aspek Pelatihan Motivasi Keyakinan Diri

Pelatihan motivasi keyakinan diri dipandang sebagai intervensi dengan memberikan pengetahuan tentang efikasi diri kepada peserta pelatihan. Materi pelatihan motivasi keyakinan diri merupakan sumber informasi yang akan diproses menjadi knowledge bagi subjek yang diberi pelatihan. Materi pelatihan motivasi keyakinan diri disusun meliputi aspek-aspek pelatihan motivasi keyakinan diri yang dikemukakan oleh Bandura (1997) sebagai berikut:

a). Mengenali potensi diri

Merupakan pemahaman untuk mengenali kelebihan dan kekurangan diri sendiri. Bandura (1997) mengemukakan bahwa penting bagi individu untuk mengetahui kondisi awal keyakinan diri yang dimilikinya. Pengungkapan kondisi awal keyakinan diri tidak hanya pada tingkat individu tetapi uga sampai pada tingkat kolektivitas. Hal ini disebabkan karena ruang lingkup keyakinan diri tidak hanya terkait pada satu individu tetapi mencakup juga individu lain. Secara spesifik pengenalan potensi diri tidak hanya terbatas pada penilaian individu secara langsung tetapi juga merupakan hasil kolektivitas dari individu lain yang terlibat dalam lingkungan sekitarnya. Karyawan yang mengenali potensi yang ada dalam dirinya maka ia akan 
memiliki motivasi keyakinan diri untuk menyelesaikan tugas pekerjaannya.

b). Kemampuan untuk membentuk persepsi positif.

Konsep triadic reciprocal causation menjelaskan bahwa konsep dan situasi lingkungan mempunyai hubungan timbal balik terhadap perilaku dan personal faktor (cognitive, affective dan biological events). Bandura (1997) mengemukakan bahwa individu yang mempunyai tingkat efikasi yang tinggi akan mendasarkan tindakan yang dilakukan melalui pertimbangan dalam cara individu memandang masa depan dan kesadaran akan kesempatan yang dimiliki. Dapat disimpulkan bahwa kemampuan membentuk persepsi positif merupakan kemampuan untuk merubah suatu peristiwa yang dipreferensikan sebagai faktor negatif menjadi positif dengan memanfaatkan kesempatan yang dimiliki sehingga individu mampu bertindak secara objektif.

c). Personal goal

Bandura (1997) menjelaskan bahwa personal goal bepengaruh terhadap efikasi diri melalui motivasi dan tujuan pribadi. Perilaku individu diarahkan dan dimotivasi oleh tujuan yang ingin dicapai, dengan kata lain tujuan yang ingin dicapai individu memberikan akibat secara langsung pada reaksi dan tindakan yang akan dilakukan oleh individu. Maka personal goal diartikan sebagai proses penetapan sasaran atau tujuan dalam bidang pekerjaan untukmencapai keberhasilan mencapai kinerja yang maksimal.

d). Daya juang

Bandura (1997) mengemukakan

bahwa efficacy beliefs berkontribusi melalui motivasi dalam kerangka efikasi diri terutama dalam memilih tantangan yang akan dihadapi, usaha yang perlu untuk diupayakan dan ketahanan dalam menghadapi kesulitan.

\section{Peningkatan Efikasi Diri Melalui Pelatihan Motivasi Keyakinan Diri}

Pelatihan motivasi keyakinan diri bertujuan untuk meningkatkan efikasi diri pegawai Universitas $X$ sehingga materi pelatihan disusun sedemikian rupa untuk dapat memberikan insight pada karyawan untuk meningkatkan keyakinan dirinya..

Berdasarkan teori Bandura disusun materi pelatihan motivasi keyakinan diri yang diharapkan dapat meningkatkan efikasi diri karyawan mencakup aspek pengenalan potensi diri, persepsi positif, personal goal dan aspek daya juang. Aspek pengenalan potensi diri merupakan wujud dari peniliain pada kemampuan individu, hal ini ditentukan oleh penilaiannya pada kemampuan yang dimiliki dan potensi dari kemampuan individu yang telah dimiliki dan kemampuan yang tidak dimiliki namun tidak disadari. Pengenalan potensi diri yang tepat akan menjadikan pegawai Universitas X mampu menghasilkan kemampuan penilaian diri yang tepat sehingga mampu memperkuat keyakinannya untuk melakukan tindakan yang diperlukan dalam pekerjaannya.

\section{METODE PENELITIAN}

\section{Variabel Penelitian}

Varabel-variabel yang digunakan dalam penelitian ini adalah:

1. Variabel tergantung : Efikasi Diri

Bandura (1997) definisi efficacy adalah suatu kemampuan yang diturunkan dari ketrampilan kognitif, sosial, emosional, dan keperilakuan yang diorganisasikan dan disusun secara efektif untuk mencapai tujuan. Selanjutnya, Bandura (1997) menyatakan bahwa perceived self efficacy mengacu pada keyakinan seseorang terhadap kemampuannya untuk mengorganisir dan melaksanakan berbagai tindakan yang diperlukan untuk memperoleh pencapaian yang tertentu. Efikasi diri pada karyawan adalah keyakinan diri yang dimiliki karyawan untuk mampu menyelesaikan tugas-tugas pekerjaan yang dihadapi.

Variabel efikasi diri diukur menggunakan skala efikasi diri yang disusun oleh peneliti berdasarkan dimensi yang dikemukakan oleh Bandura (1977) yaitu tingkat tugas, luas bidang dan tingkat 
kekuatan. Skor total skala efikasi diri menujukkan efikasi diri pada subjek. Semakin tinggi skor total maka semakin tinggi efikasi diri yang dimiliki oleh subjek sebaliknya semakin rendah skor total maka semakin rendah pula efikasi diri yang dimiliki oleh subjek.

2. Variabel bebas : Pelatihan Motivasi Keyakinan Diri

Pelatihan motivasi keyakinan diri adalah proses pendidikan dalam jangka waktu yang relatif pendek dengan menggunakan prosedur yang sistematis dan terorganisir sehingga tenaga kerja non manajerial dapat mempelajari pengetahuan dan keterampilan teknis untuk tujuan tertentu, dalam hal ini yaitu peningkatan efikasi diri karyawan.

Materi pelatihan motivasi keyakinan diri disusun berdasarkan aspek-aspek pelatihan motivasi keyakinan diri yang dikemukakan oleh para ahli ( Lee \& Bobkoo, 1994; Graham \& Weiner, 1996; Barnhardt 1997; Philips \& Gully 1997; Dewcks, 2000; Pintrich, 2000; Jex dkk, 2001; Chick \& Vincent, 2005) meliputi :

a). Mengenali potensi diri

Pemahaman untuk mengenali kelebihan dan kekurangan diri sendiri. Pengenalan potensi diri tidak hanya terbatas pada penilaian individu secara langsung tetapi juga merupakan hasil kolektivitas dari individu lain yang terlibat dalam lingkungan sekitarnya. Karyawan yang mengenali potensi yang ada dalam dirinya maka ia akan memiliki motivasi keyakinan diri untuk menyelesaikan tugas pekerjaannya.

b). Kemampuan untuk membentuk persepsi positif.

Persespsi diri dari berfikir negative menjadi positif, serta melakukan self talk positive. Individu yang mempunyai pesrsepsi positif maka ia akan memiliki hubungan yang baik dengan rekan kerja dan atasan, selain itu ia akan memiliki keyakinan diri untuk mampu melakukan dan menyelesaikan tugas pekerjaannya. Karyawan yang mampu membentuk persepsi positif dalam dirinya maka ia akan memiliki motivasi keyakinan diri untuk menyelesaikan tugas pekerjaannya.

c). Personal goal

Perilaku individu diarahkan dan dimotivasi oleh tujuan yang ingin dicapai, dengan kata lain tujuan yang ingin dicapai individu memberikan akibat secara langsung pada reaksi dan tindakan yang akan dilakukan oleh individu. Maka personal goal diartikan sebagai proses penetapan sasaran atau tujuan dalam bidang pekerjaan untukmencapai keberhasilan mencapai kinerja yang maksimal. Karyawan yang merencanakan personal goal yang ada dalam dirinya maka ia akan memiliki motivasi keyakinan diri untuk menyelesaikan tugas pekerjaannya.

d). Daya juang

Daya juang individu untuk dapat bertahan dan menyelesaikan setiap kesulitan dalam pekerjaannya. Karyawan yang mempunyai daya juang yang baik dalam dirinya maka ia akan memiliki motivasi keyakinan diri untuk menyelesaikan tugas pekerjaannya

\section{Desain Penelitian}

Penelitian ini menggunakan metode kuantitatif dan kualitatif. Metode kuantitatif menggunakan pendekatan Quasi Eksperimental dengan metode Pretest-Posttest Control Group Design. Pendekatan model Quasi Eksperimental merupakan model eksperimen yang dilakukan tanpa randominasi namun masih menggunakan kelompok kontrol.

Dalam penelitian ini pengukuran efikasi diri dilakukan pada tiga tahap pengukuran sesuai dengan yang dilakukan Neck \& Manz (1996). Pengukuran efikasi diri dilakukan sebanyak tiga tahap yaitu sebelum pelatihan (pre test), setelah dilakukan pelatihan (post test 1) sehingga terdapat tiga data efikasi diri pegawai Universitas $X$.

\section{Subjek Penelitian}

Subjek yang digunakan dalam penelitian ini adalah pegawai Universitas $X$ 
sejumlah 54 karyawan. Jumlah tersebut kemudian dikelompokkan menjadi dua kelompok subjek yaitu 27 subjek sebagai kelompok eksperimen dan 27 subjek kontrol. Pengelompokan subjek penelitian menjadi subjek kelompok kontrol dan kelompok penelitian dilakukan dengan cara undian. Penulis memasukkan nama-nama subjek penelitian dalam lintingan kecil kertas undian kemudian mengambil 27 lintingan kertas undian. Nama-nama yang keluar pada kocokan pertama dijadikan sebagai subjek kelompok eksperimen sedangkan sisanya dijadikan sebagai kelompok kontrol.

\section{Assesment}

\section{Prosedur Assesment}

\section{a. Tahap persiapan assesment}

Sebelum melakukan proses assessment ada beberapa hal yang perlu dipersiapkan, yaitu:

1). Penyusunan modul dan alat ukur

Penyusunan modul dan materi pelatihan mengacu pada teori yang dikemukakan oleh Bandura (1997), meliputi aspek-aspek tingkat tugas, luas bidang tugas, tingkat kekuatan. Modul pelatihan berisi tentang materi yang akan diberikan meliputi aspek-aspek pelatihan yaitu:

a). Mengenali potensi diri

Merupakan pemahaman untuk mengenali kelebihan dan kekurangan diri sendiri. Pengenalan potensi diri tidak hanya terbatas pada penilaian individu secara langsung tetapi juga merupakan hasil kolektivitas dari individu lain yang terlibat dalam lingkungan sekitarnya. Karyawan yang mengenali potensi yang ada dalam dirinya maka ia akan memiliki motivasi keyakinan diri untuk menyelesaikan tugas pekerjaannya.

b). Kemampuan untuk membentuk persepsi positif.

Kemampuan membentuk persepsi positif merupakan kemampuan untuk merubah suatu peristiwa yang dipreferensikan sebagai faktor negatif menjadi positif dengan memanfaatkan kesempatan yang dimiliki sehingga individu mampu bertindak secara objektif dan dari kurang mampu menjadi yakin untuk menyelesaikan tugas pekerjaan.

c). Personal goal

Personal goal diartikan sebagai proses penetapan sasaran atau tujuan dalam bidang pekerjaan untukmencapai keberhasilan mencapai kinerja yang maksimal. Penetapan tujuan dapat mempengaruhi individu dalam menghadapi tantangan.

d). Daya juang

Daya juang berkontribusi melalui motivasi dalam kerangka efikasi diri terutama dalam memilih tantangan yang akan dihadapi, usaha yang perlu untuk diupayakan dan ketahanan dalam menghadapi kesulitan.

Modul pelatihan juga berisi blue-print pelatihan motivasi keyakinan diri, lembar kerja dan lembar evaluasi. Alat ukur yang disusun dalam penelitian ini berdasarkan teori yang disusun oleh Bandura (1997), meliputi skala efikasi diri dan jajak pengetahuan.

Tabel 1. Blue print skala efikasi diri sebelum uji coba

\begin{tabular}{|l|l|l|l|}
\hline $\begin{array}{l}\text { Dimensi } \\
\text { Efikasi } \\
\text { Diri }\end{array}$ & Favo & Unfav & Jumlah \\
\hline $\begin{array}{l}\text { Tingkat } \\
\text { tugas }\end{array}$ & $\begin{array}{l}1,2,3,4,5, \\
6,7,8\end{array}$ & $\begin{array}{l}9,10,11, \\
12,13,14, \\
15\end{array}$ & 15 \\
\hline $\begin{array}{l}\text { Luas } \\
\text { bidang } \\
\text { tugas }\end{array}$ & $\begin{array}{l}23,24,25,27,28, \\
29,30\end{array}$ & $\begin{array}{l}16,17,18,20,21, \\
22\end{array}$ & 15 \\
\hline $\begin{array}{l}\text { Kekuata } \\
\mathrm{n}\end{array}$ & $\begin{array}{l}31,32,33,35,36, \\
34,39,40,\end{array}$ & $\begin{array}{l}31,42,43, \\
44,45\end{array}$ & 15 \\
\hline Jumlah & 23 & 22 & 45 \\
\hline
\end{tabular}

yang diberikan selama pelatihan berlangsung. Pembekalan dilaksanakan dengan cara sharing dan diskusi.

2). Uji coba alat ukur

Uji coba alat ukur dilakukan pada tanggal 13 Agustus 2016 di Universitas X Palangkaraya dengan jumlah subjek 30 orang. Subjek yang digunakan dalam uji coba alat ukur ini bukan merupakan subjek 
penelitian. Alat ukur yang digunakan dalam penelitian adalah skala efikasi diri.

Koefisien reliabilitas skala efikasi diri adalah 0,929. Hasil dari korelasi aitem total dengan skor total Skala efikasi diri menghasilkan rit (korelasi aitem total) dengan kisaran antara 0,233 sampai 0,795. Rata-rata rit (korelasi aitem total) skala efikasi diri adalah 0,587. Blue print skala efikasi diri setelah uji coba disajikan pada tabel 2.

Tabel 2. Blue print skala efikasi diri setelah uji coba

\begin{tabular}{|c|c|c|c|c|c|c|}
\hline \multirow{2}{*}{$\begin{array}{l}\text { Dimensi } \\
\text { Efikasi } \\
\text { Diri }\end{array}$} & \multicolumn{2}{|c|}{ Favorable } & \multicolumn{2}{|c|}{ Unfavorable } & \multicolumn{2}{|c|}{ Jumlah } \\
\hline & $\mathbf{V}$ & TV & $\mathbf{V}$ & TV & $\mathbf{V}$ & TV \\
\hline $\begin{array}{l}\text { Tingkat } \\
\text { tugas }\end{array}$ & 3,4 & $\begin{array}{l}1,2, \\
5,6, \\
7,8\end{array}$ & $\begin{array}{l}9, \quad 10, \\
11,12, \\
13,14\end{array}$ & 15 & 8 & 7 \\
\hline $\begin{array}{l}\text { Luas } \\
\text { bidang } \\
\text { tugas }\end{array}$ & $\begin{array}{l}23, \\
24, \\
25, \\
26, \\
27\end{array}$ & $\begin{array}{l}28 \\
29 \\
30\end{array}$ & $\begin{array}{l}17,19, \\
22\end{array}$ & $\begin{array}{l}16,18 \\
20,21\end{array}$ & 8 & 7 \\
\hline $\begin{array}{l}\text { Kekuata } \\
\text { n }\end{array}$ & $\begin{array}{l}32, \\
33 \\
34\end{array}$ & $\begin{array}{l}31, \\
35, \\
36, \\
37\end{array}$ & $\begin{array}{l}38,39 \\
40,41 \\
43\end{array}$ & $\begin{array}{l}42,44, \\
45\end{array}$ & 8 & 7 \\
\hline Jumlah & 10 & 13 & 14 & 8 & 24 & 21 \\
\hline
\end{tabular}

efikasi diri selanjutnya disusun kembali dengan penomoran baru. Skala efikasi diri dengan nomor baru akan digunakan sebagai alat pengumpul data. Distribusi aitem skala efikasi diri dengan nomor baru dapat dilihat pada tabel 3 .

Tabel 3. Distribusi item skala efikasi diri dengan nomor baru

\begin{tabular}{|l|l|l|l|}
\hline $\begin{array}{l}\text { Dimensi } \\
\text { Efikasi } \\
\text { Diri }\end{array}$ & Favorable & Unfavorable & Jumlah \\
\hline $\begin{array}{l}\text { Tingkat } \\
\text { tugas }\end{array}$ & 1,2 & $3,4,5,6,7,8$ & 8 \\
\hline $\begin{array}{l}\text { Luas } \\
\text { bidang } \\
\text { tugas }\end{array}$ & $\begin{array}{l}12,13,14,16 \\
15,10,11\end{array}$ & 8 \\
\hline Kekuatan & $17,18,19$ & $\begin{array}{l}20,21,22,24 \\
23,24\end{array}$ & 8 \\
\hline Jumlah & 10 & 14 & 24 \\
\hline
\end{tabular}

\section{E. Intervensi}

\section{Prosedur Intervensi}

Subjek yang mengikuti pelatihan motivasi keyakinan diri merupakan subjek yang berasal dari kelompok eksperimen, yang sebelumnya sudah

diberikan pre-test.

a. Pelaksanaan pelatihan motivasi keyakinan diri

Pemberian intervensi pelatihan motivasi keyakinan diri selama lima sesi yang dilaksanakan pada tanggal 7-8 Oktober 2016.

Penentuan waktu pelaksanaan pelatihan motivasi keyakinan diri dengan pertimbangan agar pelatihan yang diberikan tidak mengganggu jam kerja pegawai selain itu dilakukan pelatihan selama 2 hari diharapkan para peserta dapat menyerap materi secara maksimal sehingga intervensi dapat membuahkan hasil yang positif.

a. Post training $I$

Pengambilan data post training $I$ dilakukan setelah intervensi pelatihan motivasi keyakinan diri. Post training $I$ dilakukan pada 7 Oktober 2016 menggunakan alat test berupa skala dan wawancara dengan beberapa subjek pelatihan.

b. Self Monitoring

Self monitoring dilaksanakan pada 12 Desember 2017. Self monitoring dilakukan untuk mengetahui sejauh mana efek pelatihan motivasi keyakinan diri yang diberikan masih bertahan dalam diri subjek. Metode yang digunakan adalah wawancara.

\section{Metode Intervensi}

Intervensi diberikan kepada subjek dalam bentuk pelatihan motivasi keyakinan sebanyak empat sesi selama dua hari berturut-turut, dengan garis besar pelatihan dijelaskan dalam tabel 6.

Pelatihan motivasi keyakinan diri bertujuan untuk meningkatkan keyakinan diri dalam melaksanakan tugas-tugas pekerjaan. Setiap sesi pelatihan berlangsung selama 30-60 menit dengan melibatkan pelatih dan fasilitator yang dinilai telah berpengalaman dan memiliki kompetensi dibidangnya. 
Metode Analisis Data

\section{Analisis kuantiatif}

Dalam penelitian ini data-data yang diperoleh akan dianalisis dengan analisis teknik Independent Sample $t$ - test untuk mengetahui perbedaan efikasi diri antara kelompok eksperimen yang diberikan perlakuan pelatihan motivasi keyakinan diri dengan kelompok kontrol. Hasil analisis ini juga digunakan untuk menguji hipotesis dalam penelitian ini.

\section{Analisis Kualitatif}

Analisis kualitatif digunakan dalam penelitian ini untuk menunjang hasil dari analisis Independent Sample $t$-Test dengan tujuan untuk mengetahui perubahan efikasi diri subjek setelah mendapatkan pelatihan efikasi diri. Data untuk analisis kualitatif berasal dari hasil interview, hasil observasi saat pelatihan berlangsung dan hasil evaluasi subjek.

\section{HASIL PENELITIAN}

Untuk menjawab rumusan yang pertama apakah gaya kepemimpinan yang diterapkan Rektor di UM Palangkaraya cenderung merupakan tipe kepemimpinan transformasional, diketahui dari hasil uji triangulasi dan analisis pembahasan adalah :

\section{PEMBAHASAN}

Berdasarkan hasil analisis data penelitian diperoleh hasil yang menunjukkan bahwa ada peningkatan efikasi diri pada pegawai Universitas X. Tingginya efikasi diri diketahui dari pengukuran efikasi diri menggunakan skala efikasi diri yang dilakukan sebanyak tiga tahap. Tahap pengukuran tersebut yaitu tahap sebelum pelatihan motivasi keyakinan diri (pre training), dua bulan setelah pelatihan motivasi keyakinan diri (post training 1) dan empat bulan setelah pelatihan motivasi keyakinan diri (post training 2).

Perbedaan tingkat efikasi diri pegawai Universitas $X$ ditunjukkan dengan hasil uji Paired Samples $t$ Test yang memperoleh hasil bahwa terdapat perbedaan tingkat efikasi diri pada fase sebelum dilakukan pelatihan, dua bulan setelah pelatihan dan empat bulan setelah pelatihan. Perbedaan tingkat efikasi diri tersebut dapat dilihat pada hasil analisis pair pertama yaitu tahap pre training -post training 1 (nilai $\mathrm{t}=-17,082$ dengan taraf signifikansi $\mathrm{p}=0.000)$, pair kedua yaitu tahap pre training - post training 2 (nilai $\mathrm{t}=-17,737$ dengan taraf signifikasi $\mathrm{p}=0.000$ ) dan pair ketiga yaitu tahap post training 1 - post training 2 (nilai $\mathrm{t}=-5,318$ dengan taraf signifikansi $\mathrm{p}=0,000)$. Artinya bahwa terdapat perbedaan tingkat efikasi diri pegawai Universitas $X$ baik pada saat sebelum dilakukan pelatihan maupun setelah dilakukan pelatihan motivasi keyakinan diri baik pada jangka pendek maupun jangka panjang pasca pelatihan.

Hasil analisis kuantitatif

menunjukkan rata-rata skor efikasi diri pegawai Universitas $X$ pada tahap sebelum pelatihan (pre training) adalah 70,55. Rata-rata tersebut mengalami peningkatan dalam jangka pendek yaitu dua bulan setelah dilakukan pelatihan (post training 1) menjadi 92,09 . Peningkatan kembali terjadi dalam jangka panjang yaitu pada kurun waktu empat bulan setelah dilakukan pelatihan motivasi keyakinan diri (post training 2) dengan rata-rata 95,29. Perbedaan rata-rata efikasi diri pada tiap tahap pengukuran menunjukkan bahwa telah terjadi efikasi diri yang tinggi pada pegawai Universitas $X$ pada tahap sebelum dilakukan pelatihan dan setelah dilakukan pelatihan baik pada jangka pendek maupun jangka panjang. Efikasi diri pegawai Universitas X setelah pelatihan lebih tinggi dibandingkan dengan sebelum diberikan pelatihan motivasi keyakinan diri. Hal disebabkan pelatihatan motivasi keyakinan diri memberikan pengetahuan dan insight yang dapat menyebabkan perubahan efikasi.

Pernyataan tersebut didukung oleh pendapat Bandura (1997) yang menyatakan bahwa efikasi adalah suatu kemampuan generatif dari ketrampilan kognitif, sosial, 
emosional dan keperilakuan yang diorganisasikan dan disusun secara efektif untuk mencapai tujuan. Tingginya efikasi diri pegawai Universitas $X$ setalah pelatihan disebabkan oleh adanya peristiwa atau pengalaman yang diperoleh oleh subjek selama kurun waktu empat bulan tersebut sehingga mempengaruhi aspek kognitif, sosial, emosional, maupun keperilakuan yang dapat menyebabkan perubahan yang positif pada pegawai Universitas X.

Metode penelitian yang digunakan dalam penelitian ini mengelompokkan sampel penelitian menjadi kelompok eksperimen (mendapatkan pelatihan motivasi keyakinan diri) dan kontrol (tidak mendapatkan pelatihan motivasi keyakinan diri) maka dilakukan pengujian Independent Samples $t$ Test untuk mengetahui apakah semakin tingginya efikasi diri pada pegawai Universitas $X$ selama tiga tahap pengukuran tersebut disebabkan oleh pelatihan motivasi keyakinan diri yang diterima ataukah tidak. Hasil analisis Independent Samples $t$ Test menunjukkan bahwa pada saat sebelum pelatihan (pre training) tidak terdapat perbedaan tingkat efikasi diri eksperimen dan kontrol (nilai $t=1,096$ dengan taraf signifikansi $\mathrm{p}=0,278$ ). Dua bulan setelah pelatihan atau pada jangka pendek pasca pelatihan (post training 1) terdapat perbedaan efikasi diri pada kelompok eksperimen dan kelompok kontrol (nilai $\mathrm{t}=-2,507$ dengan taraf signifikansi $\mathrm{p}=0$, 015). Pada empat bulan setelah pelatihan pada jangka panjang pasca pelatihan (post training 2) tidak terdapat perbedaan efikasi diri pada kelompok eksperimen dan dan kelompok kontrol (nilai $t=-1,537$ dengan taraf signifikansi $p=0,130$ ).

Rata-rata efikasi diri kelompok kontrol dan kelompok eksperimen sebelum diberikan pelatihan motivasi keyakinan diri (pre training) masing-masing yaitu 71,59 untuk kelompok kontrol dan 69,51 untuk kelompok eksperimen. Jangka waktu dua bulan setelah pelatihan motivasi keyakinan diri (post training 1) terjadi peningkatan nilai rata-rata efikasi diri yaitu 90,18 untuk kelompok kontrol dan 94 untuk kelompok eksperimen. Peningkatan nilai rata-rata efikasi diri pada kelompok kontrol dan kelompok eksperimen juga terjadi pada kurun waktu empat bulan setelah pelatihan motivasi keyakinan diri yaitu 93,85 untuk kelompok kontrol dan 96,74 untuk kelompok eksperimen. Hasil tersebut menunjukkan bahwa menunjukkan bahwa sebelum pelatihan motivasi keyakinan diri tingkat efikasi diri pegawai Universitas $X$ relatif sama antara kelompok kontrol dan kelompok eksperimen. Dua bulan setelah pelatihan yang diterima oleh pegawai Universitas $X$ terjadi peningkatan efikasi diri pada kelompok kontrol dan kelompok eksperimen dimana peningkatan efikasi diri kelompok eksperimen jauh lebih tinggi dibandingkan kelompok kontrol,.

Perubahan efikasi diri yang dapat bertahan dalam jangka panjang (empat bulan) disebabkan karena para peserta pelatihan mulai menerapkan ilmu yang didapatkan seperti pembuatan rencana kerja dan target-target harian seperti yang terungkap dalam wawancara (lampiran halaman 191-193). Hal ini sesuai dengan pendapat Bandura (1997) yang menyatakan bahwa hal yang patut menjadi perhatian dalam konsep efikasi adalah adanya perbedaan antara mempengaruhi keterampilan dan mengintegrasikan keterampilan tersebut dalam tugas kemudian melakukan dengan baik tindakan tersebut dalam situasi yang sulit. Pelatihan motivasi keyakinan diri yang bermuatan materi efikasi termasuk untuk mengintegrasikannya dalam tugas-tugas menyebabkan karyawan menjadi memiliki ketrampilan yang lebih baik dalam melaksanakan pekerjaan.

Tingginya efikasi diri pada karyawan setelah pelatihan ditunjukkan dengan peningkatan masing-masing dimensi efikasi diri pada tiap tahap pengukuran. Peningkatan tersebut disebabkan karena pelatihan yang diberikan kepada karyawan memberikan pembelajaran dan pengetahuan yang berdampak pada meningkatnya 
keyakinan pada karyawan untuk dapat menyelesaikan tugas pekerjaannya. Hasil analisis tiap dimensi efikasi diri menunjukkan bahwa masing-masing dimensi efikasi diri mengalami peningkatan pada tiap tahap pengukuran.

Dimensi tingkat tugas mengalami peningkatan yang pada sebelum diberikan pelatihan dibandingkan dengan pada saat setelah diberikan pelatihan. Hal ini menunjukkan bahwa pelatihan motivasi keyakinan diri memberikan kontribusi kepada karyawan yaitu meningkatkan keyakinan pada diri karyawan untuk menyelesaikan tugas yang memiliki tingkat tugas yang berbeda. Artinya setelah pelatihan karyawan memiliki keyakinan yang lebih tinggi bahwa dirinya mampu dalam menyelesaikan tugas pekerjaan dengan tingkat kesulitan yang berbeda mulai dari tugas dengan tingkat kesulitan paling mudah hingga yang paling sukar.

Peningkatan pada dimensi tingkat kekuatan menunjukkan bahwa setelah pelatihan karyawan memiliki daya juang yang lebih tinggi dibandingkan sebelum pelatihan. Pelatihan motivasi keyakinan diri terbukti mampu meningkatkan keyakinan yang kuat dan ketekunan dalam usaha untuk menyelesaikan tugas pekerjaannya meskipun menghadapi hambatan dan rintangan.

Dimensi luas bidang tugas mengalami peningkatan yang paing baik dibandingkan dua dimensi efikasi diri lainnya yaitu dimensi tingkat tugas (level) dan dimensi tingkat kekuatan (strength). Hal ini dapat diintepretasikan bahwa karyawan mengalami peningkatan pemahaman yang berkaitan dengan cakupan bidang tingkah laku dimana karyawan merasa yakin terhadap kemampuannya dalam menyelesaikan tugastugas pekerjaannya. Artinya individu mampu menilai keyakinan dirinya dalam menyelesaikan tugas pekerjaannya dibanyak bidang atau dalam bidang tertentu saja. Mampu atau tidaknya individu dalam mengerjakan bidang-bidang dan konteks tertentu mengungkapkan gambaran secara umum tentang efikasi diri yang dimilikinya. Generalisasi bisa bervariasi dalam beberapa bentuk dimensi yang berbeda termasuk tingkat kesamaan aktivitas dan modalitas dimana kemampuan diekspresikan yang mencakup tingkah laku kognitif, afektif dan konatif.

Berdasarkan hasil analisis Independent t-Test pada post training 2 antara kelompok kontrol dan kelompok eksperimen diketahui bahwa tidak ada perbedaan yang signifikan antara kelompok kontrol dan kelompok eksperimen salah satunya disebabkan oleh faktor lingkungan. Faktor lingkungan yang mempengaruhi kelompok kontrol disebut sebagai diffusion of treatment. Hal ini terjadi apabila subjek dari kelompok yang berbeda (kontrol dan eksperimen) saling berkomunikasi dan mengalami proses pembelajaran manipulasi (Leedy 1997).

\section{KESIMPULAN}

Berdasarkan hasil penelitian dapat disimpulkan bahwa pelatihan motivasi keyakinan diri berpengaruh terhadap peningkatan efikasi diri pegawai Universitas $X$ Palangkaraya. Tingginya efikasi diri karyawan akan memotivasi melaksanakan atau menyelesaikan tugas-tugas pekerjaan yang dihadapi.

\section{SARAN}

Berdasarkan hasil penelitian dapat diajukan beberapa saran yaitu:

1. Bagi Universitas $X$

Menyarankan bahwa pelatihan motivasi keyakinan diri berpengaruh terhadadap efikasi diri, oleh karena itu dalam usaha meningkatkan efikasi diri karyawan perlu diberikan pelatihan motivasi keyakinan diri.

2. Bagi peneliti selanjutnya

a. Menyarankan pada para peneliti selanjutnya bahwa pelatihan motivasi keyakinan diri secara empirik dapat meningkatkan efikasi diri, oleh karena itu hasil penelitian ini dapat digunakan sebagai landasan penelitian selanjutnya . 
Kepada peneliti yang ingin melakukan penelitian sejenis disarankan untuk mengkaji faktor-faktor yang mempengaruhi efikasi diri menggunakan sehingga dapat diketahui kontribusi faktor-faktor tersebut terhadap efikasi diri antara lain yaitu pencapaian yang sukses, pengalaman orang lain dan persuasi sosial.

\section{REFERENSI}

Ancok, D. (2002). Outbound Management Training:Aplikasi Ilmu Perilaku dalam Pengembangan Sumber Daya Manusia. Yogyakarta :UII Press.

Bandura, Albert, (1977), “Self-efficacy: Toward a Unifying Theory of Behavioral Change", Psychological Review, Volume 84, No 2, halaman 191-215

Bandura, Albert, (1984), "Perceived SelfEfficacy in Cognitive Development and Functioning", Journal of Applied Psychology, Volume 69, No 2, halaman 241-251

Bandura, A. (1997). Efikasi diri. The Exercise of a Control. New York : W.H. Freeman and Company.

Cervone, D. \& Wood, R.E. 1995. Goals, Feedback and The Differential Influence of Self - Regulatory Processes on Cognitively Complex Performance. Cognitive Theraphy and Research, 19, (1), 519-545.

Cummings, T.G. \& Worley, C.G. 2005.Organization Development and Change : Eight Edition. Amerika :Thomson South Western

Daan van Knippenberg, (2000), “Work Motivation and Performance: A Social Identity Perspective", Applied Psychology : An International Review, 2000, Volume 49, No 3, halaman 357371

Dessler, G. 1997. Manajemen Sumber Daya Manusia. Edisi Bahasa Indonesia jilid I. Jakarta : Prenhallindo

Harahap, Dewi Handayani, (2010), “Diagnosa Organisasi Program Pengembangan Sumber Daya Manusia pada Universitas Ahmad Dahlan Yogyakarta", Laporan Internship Bidang Psikologi dan Organisasi (tidak dipublikasikan), Program Magister Profesi Psikologi Universitas Ahmad Dahlan Yogyakarta, 2010

Locke, Edwin A. (2000), "Motivation, Cognition, and Action: An Analysis of Studies of Task Goals and Knowledge", Applied Psychology : An International Review, Volume 49, No 3, halaman 408-429

Meyer, G.D. 1999. Social Psychology. New York: The McGraw Hill Companies, Inc

Neck, Christopher P, dan Manz, Charles C, (1996) "Thought self-leadership : The impact of mental strategies training on employee cognition, behavior, and affect", Educational Psychologist, Volume 28, No 2, halaman 117-148

Wood, Robert E, Paul, Atkins, and Tabarnero, Carmen, (2000), "Self efficacy and Strategy on Complex Tasks", Applied Psychology : An International Review, Volume 49, No. 3, halaman 430-446

Locke, Edwin A. Frederick, Elizabeth, Lee, Cynthia, dan Bobko, Philip, (1984), "Effect of Self-Efficacy, Goals, and Task Strategies on Task Performance, Journal of Applied Psychology, Volume 69, No 2, halaman 241-251

Karsten, Rex A dan Loomba, Arvinder P. S. (2002), "The Little Engine that Could : Self-efficacy Implications for Quality Training Outcomes, Total Quality Management, Volume 13, No. 7, halaman 971-980

Ryan, R.M., Deci, E.L. 2000. Self-Determination Theory and The Facility of Intrinsic motivation, Social Development, and well-being. American Pychologist 55, 6878. 